\title{
Social and environmental factors associated with the hospitalization of tuberculosis patients ${ }^{1}$
}

\author{
Nathália França de Oliveira² \\ Maria Jacirema Ferreira Gonçalves ${ }^{3}$
}

\begin{abstract}
Objective: to identify social and environmental factors associated with hospitalization of tuberculosis (TB) patients in Manaus, Amazonas, during 2010. Methods: this is a quantitative cross-sectional epidemiological study, with primary data collection and analysis of human immunodeficiency virus (HIV), based on seropositive status. Results: Among social factors for TB-HIV co-infection, the association between alcohol use and dependence was significant for employed workers; among non-co-infections, the association between income less than one minimum wage (U.S. \$200) and retired people, Bolsa Família Program [Family Allowance]/other social benefits was significant. Regarding environmental factors, the association was significant for TB-HIV co-infection among those not having their own house, having masonry housing and daily garbage collection; and among non-co-infection, owning their own house, no masonry housing and lack of daily garbage collection was significant. Conclusion: The findings indicated that not only social factors, but also environmental ones are associated with hospitalization of tuberculosis patients, and such associations differ according to TB-HIV co-infection. Findings revealed that the non-biological factors associated with hospitalization of tuberculosis patients should be considered when caring patients with this disease.
\end{abstract}

Descriptors: Tuberculosis; Hospitalization; Epidemiologic Factors; Co-infection.

\footnotetext{
${ }^{1}$ Paper extracted from Master's Thesis "Internação Hospitalar de Doentes com Tuberculose em Manaus e Fatores Sociais e Ambientais" presented to Universidade Federal do Amazonas, Manaus, AM, Brazil. Supported by Conselho Nacional de Desenvolvimento Científico e Tecnológico (CNPq), process \# 481423/2008-7.

2 MSc, Professor, Faculdades Integradas do Tapajós, Santarém, PA, Brazil. Scholarship holder from Fundação de Amparo à Pesquisa do Estado do Amazonas (FAPEAM).

${ }^{3} \mathrm{PhD}$, Researcher, Instituto Leônidas e Maria Deane - Fiocruz Amazônia, Manaus, AM, Brazil. Adjunct Professor, Universidade Federal do Amazonas, Manaus, AM, Brazil.
}

Corresponding Author:

Maria Jacirema Ferreira Gonçalves

Universidade Federal do Amazonas. Escola de Enfermagem de Manaus

Rua Teresina, 495

Bairro: Adrianópolis

CEP: 69057-070, Manaus, AM, Brasil

E-mail: jaciremagoncalves@gmail.com 


\section{Introduction}

Tuberculosis (TB) is endemic in Amazonas State, Brazil, and even with the advent of Aids, no significant change is evident in the epidemiological profile, when analyzing the temporal incidence of the disease(1).

The hospitalization of TB patients is indicated only for severe cases or those that are likely to abandon treatment because of the social conditions of the patient, in cases of complications of the disease, and in cases of retreatment(2). These reasons for hospitalization are detailed by the Brazilian Ministry of Health ${ }^{(3)}$, that recommends hospitalization in special cases and in accordance with the following priorities: tuberculous meningitis; unmanageable intolerance to anti-TB drugs for outpatients; general condition not allowing outpatient treatment; clinical and/or surgical complications, related or unrelated to TB requiring treatment, and/or procedure in a hospital setting; and, cases of social vulnerability, such as no fixed abode or groups most likely to drop treatment, especially in cases of retreatment, failure or multidrug resistance.

The Brazilian data records a large number of hospitalizations, especially in the state of Amazonas, where the rate of hospitalization due to TB in 2010 was 8.5 cases per 100,000 inhabitants, while in the whole of Brazil the hospitalization rate that year was 7.2 cases per 100,000 inhabitants.

Despite the magnitude of the problem, we found only a few studies published on this matter; yet, they were mostly performed with secondary data collection from medical records ${ }^{(2,4)}$ and aimed at describing the epidemiology of hospitalization(5). Both environmental and social factors are associated with TB disease, and such factors may influence the occurrence of hospitalization, especially considering Human Immunodeficiency Virus (HIV) infection, which influences the profile of hospitalization for $\mathrm{TB}^{(6)}$.

It is not clear whether the associated factors related to morbidity are the same responsible for hospitalization. In general, the criteria for hospitalization are concerned with the individual and how his body changes with the TB disease. Thus, the aim of this study was to identify the social and environmental factors associated with hospitalization of TB patients, according to their seropositive status for HIV.

\section{Materials and Methods}

This was an analytical and cross-sectional epidemiological study, which used quantitative analysis of individual data on TB patients' hospitalization in 2010, in the following referral hospitals in the city of Manaus, capital of Amazonas state: Adriano Jorge Hospital Foundation, Dr. Heitor Vieira Dourado Tropical Medicine Foundation, Getúlio Vargas University Hospital, Amazonas Children's Institute and Dr. Fajardo Children's Hospital of Amazonas.

The sample was represented by patients admitted in these hospitals, who had TB as a primary or associated diagnosis. We excluded from this study: patients undiagnosed with TB, the patient or his guardian who did not feel able to give information or refused to sign the Informed Written Consent.

Data were collected in two phases: a) interviewing patients; b) collecting data from medical records. For the analysis, the variables were grouped into the following dimensions: 1) patient characteristics (sex, age group, race); 2) social factors (education, income, source of income, origin of the patient, use of alcohol, addiction to alcohol, smoking, passive smoking and drug use); and 3) environmental factors (type of housing, persons per room, condition of employment, masonry housing, origin of water used at home, daily garbage collection).

Data analysis was stratified according to seropositive status for HIV. Data were analyzed using EpiInfo 3.5.1 and SPSS 16.0 for Windows. The continuous variables were compared by means of the Student $t$-test (normal distribution), and for categorical variables, Pearson's chisquare test or Fisher's exact test, as appropriate, with analysis of standardized residuals (SR) (significance for the positive values $\geq 1.96)^{(7)}$, to determine exactly in which category of analysis the association was significant. In all statistical tests we used a $5 \%$ significance level.

The study was reviewed and approved by the ethics committee of the Tropical Medicine Foundation, under Protocol no. 1960 (CAAE - 0006.0.114.115-09). Informed written consent was obtained from each participant. In cases in which the participant was aged less than 18 years or was someone who could not be interviewed, additional informed written consent was obtained from the parent or guardian accompanying the patient.

\section{Results}

From January to December 2010, 327 hospital admissions with tuberculosis (TB) were identified in Manaus. In $49(15.0 \%)$ cases it was not possible to conduct the interview with the patient or guardian accompanying the patient. These losses occurred as follows: two cases, due to absence from the institution in 
all attempts; eight cases, refusal of the patient; 36 cases, death occurred before the interview or the diagnosis of TB was only detected in the Death Certificate; one case, patient was on oxygen and unaccompanied; and two cases, presented mental confusion. Among the losses, $61.2 \%$ were male, with a mean age of 34.5 (standard deviation, $\mathrm{SD}=11.2$ years); there was no significant difference $(P=0.244)$ as compared to respondents. Among respondents, $57.9 \%$ were male with a mean age of 38 years $(S D=18)$.

Of the 278 cases of hospitalization in which the interview was conducted, used in this analysis, 122 (43.9\%) had TB-HIV co-infection and 156 (56.1\%) TB only (not infected with HIV). Therefore, all the analysis below corresponds to the stratification of the population of TB cases and TB-HIV co-infected cases. There was a male predominance, with the following percentage: $63.1 \%$ among TB-HIV co-infected and 53.8\% among TB cases. The average age of HIV-TB cases was 31.9 years $(S D=11.1)$ and in TB cases it was $42.8(S D=20.8)$ $(P<0.01)$. It is noteworthy that among TB-HIV coinfected cases there was high concentration in the age group of 20-29 years (35.2\%), whereas TB cases were more concentrated in the age group of 50 years and older $(37.8 \%)$.
The social factors described in Table 1 show that there was an association with TB-HIV co-infection in which the source of income was paid employment (39.3\%, and $\mathrm{P}=0.002$ ). Concerning cases with TB only, the association was observed in the category of income less than one minimum wage (30.8\%) which corresponded, in the year of data collection, to an average of U.S. $\$ 200$ - (standardized residuals $\mathrm{SR}=2.10$ and $\mathrm{P}=0.040$ ), and the source of this income was retirement and Bolsa Família Program [Family Allowance]/other social benefits (38.5\%, $S R=3.40$ and $P=0.002$ ). The mean years of schooling of TBHIV co-infected cases was 6.3 years (4 to 10 years, $\mathrm{SD}=3.7)$ and among TB cases it was only 5.3 years ( 2 to 8 years; $\mathrm{SD}=3.9$ and $\mathrm{P}=0.024$ ). We detected the existence of $16 / 278$ (5.8\%) illiterate people (not shown in Table 1), who were combined with those who completed up to 4 years of schooling, totaling $41.4 \%$ of respondents. The category of illiterate was not highlighted in the analysis because of the small proportion of the population in this category. The association was significant among TB-HIV co-infected cases with variables related to alcohol use (50.8\%, $\mathrm{SR}=3.20$ and $\mathrm{P}=0.001$ ) and alcohol dependence $(37.7 \%, S R=2.50$ and $\mathrm{P}=0.011)$.

Table 1 - Distribution of social characteristics of patients admitted with TB, according to the situation of TB-HIV coinfection, Manaus, AM, Brazil, 2010

\begin{tabular}{|c|c|c|c|c|c|c|}
\hline \multirow{2}{*}{ Variables } & \multicolumn{2}{|c|}{ TB-HIV $(n=122)$} & \multicolumn{2}{|c|}{ TB $(n=156)$} & \multirow{2}{*}{$\begin{array}{c}\text { Total }(\mathrm{n}=\mathbf{2 7 8 )} \\
\mathrm{n}(\%)\end{array}$} & \multirow{2}{*}{$\chi^{2}$ (P-value) } \\
\hline & $n(\%)$ & SR & $n(\%)$ & SR & & \\
\hline Sex & & & & & & $2.41(0.120)$ \\
\hline Male & $77(63.1)$ & 1.60 & $84(53.8)$ & -1.60 & $161(57.9)$ & \\
\hline Female & $45(36.9)$ & -1.60 & $72(46.2)$ & 1.60 & $117(42.1)$ & \\
\hline Age group (years) & & & & & & $49.67(<0.001)$ \\
\hline 0 to 19 & $9(7.4)$ & -1.30 & $19(12.2)$ & 1.30 & $28(10.1)$ & \\
\hline 20 to 29 & $43(35.2)$ & 3.60 & $24(15.4)$ & -3.60 & $67(24.1)$ & \\
\hline 30 to 39 & $39(32.0)$ & 3.50 & $23(14.7)$ & -3.50 & $62(22.3)$ & \\
\hline 40 to 49 & $23(18.9)$ & -0.10 & $31(19.9)$ & 0.10 & $54(19.4)$ & \\
\hline 50 and older & $8(6.6)$ & -6.00 & $59(37.8)$ & 6.00 & $67(24.1)$ & \\
\hline Mean (SD) & \multicolumn{2}{|c|}{$31.9(11.1)$} & \multicolumn{2}{|c|}{$42.8(20.8)$} & $38.0(18.0)$ & $(<0.001)^{\S}$ \\
\hline Schooling (years) & & & & & & $3.35(0.066)$ \\
\hline Up to 4 & $43(35.2)$ & -1.80 & $72(46.2)$ & 1.80 & $115(41.4)$ & \\
\hline 5 and More & $79(64.8)$ & 1.80 & $84(53.8)$ & -1.80 & $163(58.6)$ & \\
\hline Mean (SD) & \multicolumn{2}{|c|}{$6.3(3.7)$} & \multicolumn{2}{|c|}{$5.3(3.9)$} & $5.8(3.9)$ & $(0.024)^{\S}$ \\
\hline Income (Minimum wage*) & & & & & & $6.40(\mathbf{0 . 0 4 0})$ \\
\hline$<1$ & $24(19.7)$ & -2.10 & $48(30.8)$ & 2.10 & $72(25.9)$ & \\
\hline $1-3$ & $76(62.3)$ & 0.60 & $92(59.0)$ & -0.60 & $168(60.4)$ & \\
\hline$>3$ & $22(18.0)$ & 1.90 & $16(10.3)$ & -1.90 & $38(13.7)$ & \\
\hline Source of income & & & & & & $14.84(\mathbf{0 . 0 0 2})$ \\
\hline Paid employment & $48(39.3)$ & 3.10 & $35(22.4)$ & -3.10 & $83(29.9)$ & \\
\hline Temporary work & $34(27.9)$ & 0.00 & $44(28.2)$ & 0.10 & $78(28.1)$ & \\
\hline
\end{tabular}


Table 1 - (continuation)

\begin{tabular}{|c|c|c|c|c|c|c|}
\hline \multirow{2}{*}{ Variables } & \multicolumn{2}{|c|}{ TB-HIV (n=122) } & \multicolumn{2}{|c|}{ TB $(n=156)$} & \multirow{2}{*}{$\begin{array}{c}\text { Total }(\mathrm{n}=278) \\
\mathrm{n}(\%)\end{array}$} & \multirow{2}{*}{$\chi^{2}$ (P-value) } \\
\hline & $n(\%)$ & SR & $n(\%)$ & SR & & \\
\hline $\begin{array}{l}\text { Retirement, Family Allowance and } \\
\text { other social benefits }\end{array}$ & $24(19.7)$ & -3.40 & 60 (38.5) & 3.40 & $84(30.2)$ & \\
\hline Others & $16(13.1)$ & 0.60 & 17 (10.9) & -0.60 & $33(11.9)$ & \\
\hline Origin $^{\dagger}$ & & & & & & $1.37(0.241)$ \\
\hline Capital & $100(83.3)$ & 1.10 & $118(77.6)$ & -1.10 & $218(80.1)$ & \\
\hline Other municipalities & $20(16.7)$ & -1.10 & $34(22.4)$ & 1.10 & 54 (19.9) & \\
\hline Alcohol & & & & & & $10.02(\mathbf{0 . 0 0 1 )}$ \\
\hline Yes & $62(50.8)$ & 3.20 & $50(32.1)$ & -3.20 & $112(40.3)$ & \\
\hline No & $60(49.2)$ & -3.20 & $106(67.9)$ & 3.20 & $167(59.7)$ & \\
\hline Alcohol dependence & & & & & & $6.39(0.011)$ \\
\hline Dependent & $46(37.7)$ & 2.50 & $37(23.7)$ & -2.50 & $83(29.9)$ & \\
\hline Non-dependent & 76 (62.3) & -2.50 & $119(76.3)$ & 2.50 & $195(70.1)$ & \\
\hline Smoking & & & & & & $4.51^{\ddagger}(0.203)$ \\
\hline Light (dependence) & $34(27.6)$ & 1.20 & $34(21.7)$ & -1.20 & $68(24.3)$ & \\
\hline Average (dependence) & $4(3.3)$ & 1.60 & $1(0.6)$ & -1.60 & $5(1.8)$ & \\
\hline High (dependence) & $4(3.3)$ & 0.30 & $3(1.9)$ & -0.30 & $7(2.5)$ & \\
\hline No smoking & $81(65.9)$ & -1.70 & $119(75.8)$ & 1.70 & $200(71.4)$ & \\
\hline Passive smoking & & & & & & $0.59(0.439)$ \\
\hline Yes & $12(9.8)$ & -0.80 & $20(12.8)$ & 0.80 & $32(11.5)$ & \\
\hline No & $110(90.2)$ & 0.80 & $136(87.2)$ & -0.80 & $246(88.5)$ & \\
\hline Use of illegal drugs & & & & & & $1.53(0.214)$ \\
\hline Yes & $24(19.7)$ & 1.20 & $22(14.1)$ & -1.20 & $46(16.5)$ & \\
\hline No & $98(80.3)$ & -1.20 & $134(85.9)$ & 1.20 & $232(83.5)$ & \\
\hline
\end{tabular}

$\mathrm{SD}=$ standard deviation; $\mathrm{SR}=$ standardized residuals; $\mathrm{TB}=$ tuberculosis; HIV= Human Immunodeficiency Virus

*Value of minimum wage in $2010=$ average of U.S. $\$ 200$

+ Number of cases $=272$

¥Fisher's Exact Test

$\S$ Student t-test.

Note: in bold are the residuals with a positive value $\geq 1.96$, which corresponds to the level of significance for the excess events in the categories.

For the analysis of environmental factors, 272 admitted cases were included; six patients reported not having housing. As for the environmental factors described in Table 2, the variables that showed association between TB-HIV co-infected cases were: not having their own house $(32.5 \%, S R=2.30$ and $P=0.023)$, masonry housing (80.0\%, $S R=3.00$ and $P=0.003$ ) and daily garbage collection (90.8\%, $\mathrm{SR}=2.10$ and $\mathrm{P}=0.042)$. Among the
TB cases, the association was: owning one's own house (79.6\%, $S R=2.30$ and $P=0.023$ ), not have masonry housing (36.2\%, $S R=3.00$ and $\mathrm{P}=0.003$ ) and no daily garbage collection ( $17.8 \%, \mathrm{SR}=2.10$ and $\mathrm{P}=0.042$ ). The average number of people per household was $4.9(\mathrm{SD}=2.6)$ among TB-HIV co-infected patients, and $5.4(\mathrm{SD}=2.9)$ among the TB cases, with no significant difference between groups $(P=0.086)$ (not shown in the Table).

Table 2 - Distribution of the environmental characteristics of patients admitted with TB, according to the situation of TB-HIV co-infection in Manaus, AM, Brazil, 2010

\begin{tabular}{|c|c|c|c|c|c|c|}
\hline \multirow{2}{*}{ Variables } & \multicolumn{2}{|c|}{ TB-HIV $(n=120)$} & \multicolumn{2}{|c|}{ TB $(n=152)$} & \multirow{2}{*}{$\begin{array}{c}\text { Total }(n=272) \\
n(\%)\end{array}$} & \multirow{2}{*}{$\begin{array}{c}\chi^{2} \\
\text { (P-value) }\end{array}$} \\
\hline & n (\%) & SR & n (\%) & SR & & \\
\hline Type of housing & & & & & & $0.13(0.711)$ \\
\hline House & $104(86.7)$ & -0.10 & $134(88.2)$ & 0.10 & $238(87.5)$ & \\
\hline Other & $16(13.3)$ & 0.10 & $18(11.8)$ & -0.10 & $34(12.5)$ & \\
\hline People per sleeping room & & & & & & $1.68(0.194)$ \\
\hline Up to two & $100(83.3)$ & 1.30 & $117(77.0)$ & -1.30 & $217(79.8)$ & \\
\hline More than two & $20(16.7)$ & -1.30 & $35(23.0)$ & 1.30 & $55(20.2)$ & \\
\hline
\end{tabular}


Table 2 - (continuation)

\begin{tabular}{|c|c|c|c|c|c|c|}
\hline \multirow{2}{*}{ Variables } & \multicolumn{2}{|c|}{ TB-HIV $(n=120)$} & \multicolumn{2}{|c|}{ TB $(n=152)$} & \multirow{2}{*}{$\begin{array}{c}\text { Total }(\mathrm{n}=\mathbf{2 7 2}) \\
\mathrm{n}(\%)\end{array}$} & \multirow{2}{*}{$\begin{array}{c}\chi^{2} \\
\text { (P-value) }\end{array}$} \\
\hline & n (\%) & SR & n (\%) & SR & & \\
\hline Own house & & & & & & $5.14(0.023)$ \\
\hline Yes & $81(67.5)$ & -2.30 & $121(79.6)$ & 2.30 & $202(74.3)$ & \\
\hline No & $39(32.5)$ & 2.30 & $31(20.4)$ & -2.30 & $70(25.7)$ & \\
\hline Masonry housing & & & & & & $8.52(0.003)$ \\
\hline Yes & $96(80.0)$ & 3.00 & $97(63.8)$ & -3.00 & $193(71.0)$ & \\
\hline No & $24(20.0)$ & -3.00 & $55(36.2)$ & 3.00 & $79(29.0)$ & \\
\hline Origin of water used at home & & & & & & $5.33(0.069)$ \\
\hline Public / municipal network & $84(70.0)$ & 0.80 & $99(65.1)$ & -0.80 & $183(67.3)$ & \\
\hline Well & $34(28.3)$ & 0.30 & $41(27.0)$ & -0.30 & $75(27.6)$ & \\
\hline Other & $2(1.7)$ & -2.30 & $12(7.9)$ & 2.30 & $14(5.1)$ & \\
\hline Daily garbage collection & & & & & & $4.12(\mathbf{0 . 0 4 2 )}$ \\
\hline Yes & $109(90.8)$ & 2.10 & $125(82.2)$ & -2.10 & $234(86.0)$ & \\
\hline No & $11(9.2)$ & -2.10 & $27(17.8)$ & 2.10 & $38(14.0)$ & \\
\hline
\end{tabular}

$\mathrm{SR}=$ standardized residuals; $\mathrm{TB}=$ tuberculosis; HIV = Human Immunodeficiency Virus

Note: in bold are the residuals with a positive value $\geq 1.96$, which corresponds to the level of significance for the excess events in the categories.

\section{Discussion}

While it was not possible to conduct the interview with all admitted patients, the characteristics of these patients concerning sex and age did not show significant differences as compared to the analyzed data, minimizing selection bias, since these were the main population characteristics associated with the profile of TB patients. It is considered that it should lend credibility to the information obtained through interviews during hospitalization, even though the ideal would be a home visit, because it would allow a clear observation of the conditions in which patients live. However, as the research participants were restricted to public hospitals (although this covered most admissions recorded in Manaus that year), it is assumed to be an approximation of a social pattern of homogeneity of patients. Moreover, the interview was performed to obtain information as faithfully as possible, so one could trust the declarations of patients.

The predominance of males detected in this study follows the morbidity data in which a higher incidence of TB in men ${ }^{(8)}$ is observed; although women in Brazil have conquered an important role in society, especially as householders ${ }^{(9)}$, in the context of TB, the highest detection rate continues to occur among men. However, hospitalization potentiates social damage/loss caused by $T B$, since it sets men apart from their family and makes them unproductive during hospitalization.

Regarding age, the mean of the distribution showed significant difference between the TB-HIV coinfected cases and those with TB alone $(P<0.001)$, predominantly in the age group of 20-29 years among TB-HIV co-infected, and 50 years and over among those infected with TB only. This supported data from the World Health Organization (WHO), which estimates that two thirds of TB cases occur in young adults ${ }^{(10)}$, although one would expect that there was a higher proportion of older people, in view of the weakness caused by the disease in the elderly. However, this should also be interpreted as the result of the epidemiological profile of morbidity.

Brown, yellow and black races were prevalent in this population, primarily brown, which also coincides with the distribution of race in the study population. However, it should be pointed out that white race has not featured in hospital morbidity due to TB, confirming the results of the 2010 Demographic Census, which show that the sum of black, brown, yellow and indigenous (99.7 million) exceeds the white population (91 million)(11). The use of variables such as race and ethnicity in epidemiological studies has played an instrumental role in identifying and documenting health patterns among certain population groups, in the control of potentially confounding association factors, and disclosure of health inequities ${ }^{(12)}$.

In relation to schooling, when the Northern Region was in the initial phase of the HIV epidemic, it had the highest rate of Aids incidence in the population with higher education(13). In this study, we observed that the mean of years of schooling was higher among HIVTB co-infected cases, which corroborates the above mentioned findings, that HIV infection affects people of higher socioeconomic level, or at least this profile has not changed enough to impact the hospitalization profile of the TB-HIV co-infected patients. 
Among the social factors related to both HIV coinfected and TB only cases, we highlight the association between hospitalization and household income, in which vulnerability to TB-HIV infection is higher in middle and lower socioeconomic levels ${ }^{(14)}$. Although research has been performed only in public hospitals, attended by those of lower income when compared to private hospitals, we observed a difference in which the lowest income ( $<1$ minimum wage) had significant association between those with TB only, but not in the TB-HIV coinfected cases.

Among the social factors related to TB-HIV co-infected cases, we highlight the association for hospitalization related to alcohol use and dependence, confirming other studies that showed strong association between TB and alcoholism, which is understandable because cachexia due to alcoholism predisposes individuals to low immunity(15), increased by the establishment of co-infection, leading to hospitalization. Thus it is very important to know that profile, so that we can effectively intervene on health actions, and recognize in the outpatient clinic patients those who use alcohol or drugs, known as risk factors for hospitalization.

As for environmental factors related to both HIV co-infected and uninfected cases, an association was identified for hospitalization related to residential development. This reflects the spread of diseases related to poverty and degradation of living conditions, which is a result of urbanization and uncontrolled population growth in the region, occurring without plans for the supply of basic health services(16), which reinforces the primary role of the State in providing essential health services (such as water and sanitation) and in the regulation of goods and services with remarkable impact on health (such as tobacco, alcohol and food)(17). The more concentrated and less airy household environments put people who inhabit them in close proximity, favoring the transmission of airborne diseases such as TB. Also, there is a concentration of many other people living under unfavorable conditions such as malnutrition, reduced access to health services and sanitation ${ }^{(18)}$.

By identifying the social and environmental profile of patients hospitalized with TB in Manaus, the multidisciplinary team will be able to develop in a joint and integrated way, according to their specific assignments, preventive actions to promote the quality of life of patients, and interventions for health recovery and rehabilitation. This can happen both in the health unit and in other community (external) spaces, combining clinical and technical work with health practices in the community ${ }^{(19)}$, as well as social support practices ${ }^{(20)}$, because the social aspect not only influences people to become sick with TB, but also can lead to their hospitalization. In this way, we must consider the environmental and social aspects in which the individual belongs. Nurses in particular, through the systematization of nursing care and actions of the TB control program, are able to play a role in the control program, promoting community participation in the health care being developed(20-21).

As a result of this work, and considering the percentage of hospital discharges due to clinical improvement (76.6\%) and death (20.9\%) among hospitalized TB patients, we wondered about actions for TB control in primary care, in which the Brazilian National Tuberculosis Control Program recognizes the importance of expanding the fight against TB to all health care within the Brazilian Unified Health System (SUS). Therefore, aiming at the integration of TB control in primary care, including the Brazilian Family Health Program (PSF) to ensure the effective expansion of access to diagnosis and treatment ${ }^{(22)}$ with the aim of care integration using a health care network ${ }^{(23)}$ this should be done with the consideration that the environmental and social aspects greatly influence the profile of hospitalization of TB patients.

\section{Conclusion}

The results of this research indicate a wider vision about the aspect of tuberculosis in the hospital which goes beyond the problem in primary health care. The findings detected that social and environmental factors are also associated with hospitalization. Therefore, health professionals should be aware of this association to address health care in TB patients, taking into account the social and environmental aspects.

The care provided to HIV-positive patients should take into account the social and environmental factors identified in TB patients in Manaus, to avoid hospitalization or other unfavorable outcomes. An emphasis on nonbiological factors that are involved in HIV status can contributes to the knowledge of interaction between TB and HIV, including on environmental and social contexts.

The identified social and environmental factors reflect the profile of the group of cases studied, whether they are TB-HIV co-infected or TB cases only. It is considered that the environmental aspect denotes the social context of these patients, making these factors so interwoven that often the classification of social or 
environmental factor is just a matter of semantics. These factors allow for the choice of the best health interventions, although this is not the aim of this work; however, its intent is to help prevent and minimize risks, thereby contributing to the care developed by the multidisciplinary team, nursing in particular, through consultation and nursing care systematization.

From these results and innovation of this study, in addressing the social and environmental factors associated with hospitalization of patients in the city of Manaus and the limitations identified, this issue should be examined in further studies, especially including the assessment of nursing care for hospitalized patients, according to the environmental and social factors identified here as associated with TB and TB-HIV coinfection.

\section{Acknowledgements}

To the research group involved in the project entitled "Hospital Morbidity for Tuberculosis and Associated Factors in the city of Manaus - AM"

\section{References}

1. Levino A, Oliveira RM. Tuberculose na população indígena de São Gabriel da Cachoeira, Amazonas, Brasil. Cad Saúde Pública. 2007;23(7):1728-32.

2. Caliari JDS, Figueiredo RMD. Perfil de pacientes com tuberculose internados em hospital especializado no Brasil. Rev Panam Infectol. 2007;9(4):30-5.

3. Ministério da Saúde (BR). Secretaria de Vigilância em Saúde. Manual de Recomendações para o Controle da Tuberculose no Brasil. Brasília (DF): Ministério da Saúde; 2011.

4. Galesi, VMN, Almeida MMMB. Indicadores de morbimortalidade hospitalar de tuberculose no Município de São Paulo. Rev Bras Epidemiol. 2007;10(1):48-55.

5. Arcêncio RA, Oliveira MF, Villa TCS. Internações por tuberculose pulmonar no Estado de São Paulo no ano de 2004. Ciênc Saúde Coletiva. 2007;12(2):409-17.

6. Silva DR, Menegotto DM, Schulz LF, Gazzana MB, Dalcin PTR. Características clínicas e evolução de pacientes imunocomprometidos não HIV com diagnóstico intra-hospitalar de tuberculose. J Bras Pneumol. 2010;36(4):475-84.

7. Pereira JCR. Análise de dados qualitativos: estratégias metodológicas para ciências da saúde, humanas e sociais. São Paulo: EDUSP; 2004.

8. Hargreaves JR, Boccia D, Evans CA, Adato M, Petticrew M, Porter JDH. Am J Public Health. 2011;101(4):654-62.
9. Montali L. Provedoras e co-provedoras: mulherescônjuge e mulheres-chefe de família sob a precarização do trabalho e o desemprego. Rev Bras Estud Popul. 2006;23(2):223-45.

10. World Health Organization. Global Tuberculosis Control 2010: WHO Report 2011. Geneva: World Health Organization; 2011.

11. Instituto Brasileiro de Geografia e Estatística. Censo 2010 [acesso 26 jul 2012]. Disponível em: www.ibge. gov.br.

12. Laguardia J. Raça e epidemiologia: as estratégias para construção de diferenças biológicas. Ciênc Saúde Coletiva. 2007;12(1):253-61.

13. Fonseca MGP, Szwarcwald CL, Bastos FI. Análise sociodemográfica da epidemia de Aids no Brasil, 19891997. Rev Saúde Pública. 2002;36(6):678-85.

14. Brunello MEF, Chiaravalotti-Neto F, Arcêncio RA, Andrade RLP, Magnabosco GT, Villa TCS. Áreas de vulnerabilidade para co-infecção HIV-aids/TB em Ribeirão Preto-SP, Brasil. Rev Saúde Pública. 2011;45(3):556-63. 15. Severo NPF, Leite CQF, Capela MV, Simões MJS. Características clínico-demográficas de pacientes hospitalizados com tuberculose no Brasil, no período de 1994 a 2004. J Bras Pneumol. 2007;33(5):565-71.

16. Bóia MN, Carvalho-Costa FA, Sodré FC, PorrasPedroza BE, Faria EC, Magalhães GAP, et al Tuberculose e parasitismo intestinal em população indígena na Amazônia brasileira. Rev Saúde Pública. 2009;43(1):176-8.

17. Fundação Oswaldo Cruz (BR). A saúde no Brasil em 2030: diretrizes para a prospecção estratégica do sistema de saúde brasileiro. Rio de Janeiro: Fiocruz; Ipea; Ministério da Saúde; Secretaria de Assuntos Estratégicos da Presidência da República; 2012. 323 p. 18. Vincentin G, Santo AH, Carvalho MS. Mortalidade por tuberculose e indicadores sociais no município do Rio de Janeiro. Ciênc Saúde Coletiva. 2002;7(2):253-63.

19. Valentim VL, Kruel AJ. A importância da confiança interpessoal para a consolidação do Programa de Saúde da Família. Ciênc Saúde Coletiva. 2007;12(3):777-88.

20. Sá LD, Gomes ALC, Nogueira JA, Villa TCS, Souza $\mathrm{KMJ}$, Palha PF. Intersetorialidade e vínculo no controle da tuberculose na Saúde da Família. Rev. Latino-Am. Enfermagem. 2011;19(2):387-95.

21. Oblitas FYM, Loncharich N, Salazar ME, David HML, Silva I, Velásquez D. Nursing's Role in Tuberculosis Control: a Discussion from the Perspective of Equity. Rev. Latino-Am. Enfermagem. 2010;18(1):130-8.

22. Figueiredo TMRM, Villa TCS, Scatena LM, Gonzales RIC, Ruffino-Netto A, Nogueira JA, et al. Desempenho da 
atenção básica no controle da tuberculose. Rev Saúde Pública. 2009;43(5):825-31.

23. Trigueiro JVS, Nogueira JA, Sá LD, Palha PF, Villa TCS, Trigueiro DRSG. Controle da tuberculose: descentralização, planejamento local e especificidades gerenciais. Rev. Latino-Am. Enfermagem. 2011;19(6):1289-96. 